RESEARCH ARTICLE

\title{
Insecticidal activity of Euphorbia antiquorum L. latex and its preliminary chemical analysis
}

\author{
W.A.P.P. de Silva ${ }^{1}$, G.K. Manuweera ${ }^{2}$ and S.H.P.P. Karunaratne ${ }^{1^{*}}$ \\ ${ }^{1}$ Department of Zoology, University of Peradeniya, Peradeniya. \\ ${ }^{2}$ Pesticide Registration Office, Gatambe, Peradeniya.
}

\begin{abstract}
Insecticidal properties of Euphorbia antiquorum (Euphorbiaceae) (in Sinhala: Daluke) latex was studied using the samples collected from Eppawala (Anuradhapura District), Ibbagala (Kurunegala District) and Halloluwa (Kandy District). Seven solvents i.e. dichloromethane, petroleum ether, acetone, methanol, n-hexane, distilled water and xylene were used and it was found that the insecticidal components were best extracted by xylene. Potters' sprayer method was found to be better for insect bioassays than the leaf-dip, hand sprayer and microapplicator methods. Xylene-latex extract was tested against six insect pest species, two predatory Coccinellid species and a predatory spider. The latex extract was highly toxic to soft bodied insects/ spiders. Latex collected from dry, intermediate and wet zones showed significant differences in insecticidal activities. Insecticidal activity was independent of seasonal variations. Crude extracts and cheap detergents were used to make formulations which were effective in field usage.
\end{abstract}

A preliminary analysis of toxic compounds of the latex extract was done using chromatographic techniques. Only xylene and methanol extracts gave clear spots in Thin Layer Chromatography (TLC). Comparative TLC of xylene and methanol extracts showed two additional spots in the xylene extracts. Xylene-latex extract was subjected to Florisil Column Chromatography (FCC) and eluted with n-hexane followed by petroleum ether and dichloromethane. Fourth n-hexane fraction had the highest insecticidal activity (53.25\% mortality). It gave a clear spot in TLC and a peak at 1.006 min in High Performance Liquid Chromatography (HPLC). Crude xylene-latex extracts also had the same TLC spot and the HPLC peak indicating that FCC can be used to partially purifiy the active compounds.

On storage $\left(4^{0} \mathrm{C}\right)$, both the xylene-latex extract and the $4^{\text {th }}$ n-hexane fraction were highly stable showing only a $3 \%$ decline of activity after one year.

Keywords: Euphorbia antiquorum, insecticidal properties, plant extracts, predatory insects, rice insect pests, vegetable insect pests.

\section{INTRODUCTION}

Annually, Sri Lanka loses about 25-30\% of its crops due to insect pests ${ }^{1}$. Although synthetic insecticides are used as the main controlling agent, optimal control cannot be obtained probably due to the development of insecticide resistance. Also the use of synthetic insecticides pollute the environment and can seriously affect the health of the farming communities. Therefore, a search for natural product based insecticides (botanicals), which are biodegradable and economically viable has been intensified. Resistance to botanicals does not develop as rapidly as to synthetic insecticides due to the structural complexity of natural toxicants ${ }^{2}$. Predatory insects, which play an important role in biological control, also become exposed to routinely used synthetic insecticides and are killed. Therefore, it is important to identify alternative insecticides, which exert maximum effect on the pests and minimum effect on the natural enemies of the pests.

About 250,000 plant species in the world have been reported to possess compounds with insecticidal properties $^{3}$. Traditionally, farmers in Sri Lanka have used plant products, especially from plants belonging to Family Euphorbiaceae, for pest control. Family Euphorbiaceae is the largest and the most diverse family in the plant kingdom, comprising about 7500 species in 300 genera. Euphorbiaceae plants such as Bridelia retusa (ketakala), Phyllanthus emblica (ambula), Phyllanthus reticulates (reticulated leaf flower) and Ricinus communis (endaru) have been studied for insecticidal properties by various researchers ${ }^{4,5}$.

Euphorbia antiquorum (daluke, malayan spurge tree, sesudu) (Euphorbiaceae) is a shrub/ small tree often 
found in warmer parts of Asia including Sri Lanka. The latex of the plant has been described as having emetic, purgative, diuretic, as well as toxic properties ${ }^{6-11}$. Village farmers in Sri Lanka have used the latex of E. antiquorum for insect pest control from historical times. According to past records the latex contains irritant diterpenes and triterpenes $^{9-12}$. An insecticidal compound euphol has been isolated from Jatropa curcas (Euphorbiaceae) ${ }^{13}$. Insecticidal properties of the latex of E. antiquorum (Euphorbiaceae) has been indicated in previous studies $^{14}$.

The present study was designed to identify insecticidal properties of E. antiquorum latex against a range of vegetable and rice insect pests as well as some of their predatory insects. A chemical analysis of preliminary nature was carried out with $E$. antiquorum latex to identify the active components.

\section{METHODS AND MATERIALS}

Latex extractions: Latex was collected from E. antiquorum plants from Eppawala (Anuradhapura District, $8.32^{\circ} \mathrm{N} \& 80.41^{\circ} \mathrm{E}$ ) in the Dry Zone, Halloluwa (Kandy District, $\left.7.29^{\circ} \mathrm{N} \& 80.63^{\circ} \mathrm{E}\right)$ in the Wet Zone and Ibbagala (Kurunegala District, $7.25^{\circ} \mathrm{N} \& 80.0^{\circ} \mathrm{E}$ ) in the Intermediate Zone. Dichloromethane, petroleum ether, n-hexane, acetone, xylene, methanol and distilled water were used as solvents to extract the latex. Stems of the plants were pierced and the latex was collected separately into each solvent at a latex: solvent ratio of 1:9 (10\%), centrifuged at $3500 \mathrm{rpm}$ for $5 \mathrm{~min}$ and the supernatants were stored at $4{ }^{\circ} \mathrm{C}$ until use. Further dilutions (0.01\%, $0.05 \%, 0.025 \%, 0.0125 \%, 0.006 \%$, and $0.003 \%$ ) were made in $20 \%$ newkalagen (Tekmoto, USA) solution when required.

Insects: Six species of insect pests were used for bioassays. Three vegetable pests i.e. Myzus persicae, Aphis gossypii and Aphis craccivora (aphids) were collected from cabbage, radish, wing bean, long bean, cowpea and egg plant at Horticultural Crop Research and Development Institute (HORDI), Gannoruwa and Marassana. Three rice insect pests i.e. brown planthopper (Nilaparvata lugens), paddybug (Leptocorisa oratorius) and blackbug (Scotinophara lurida) were collected from the rice fields at Rice Research and Development Institute (RRDI), Bathalagoda and HORDI, Gannoruwa. Two species of predatory ladybird beetles Harmonia octomaculata and Menochilus sexmaculatus (Cheilomenes sexmaculatus) were collected from the same fields as the aphids. The predatory spiders Lycosa pseudoannulata were collected from rice fields of Gannoruwa and Bathalagoda.

Bioassays: Bioassays were conducted using the Potters' spray method, microapplicator method, leaf-dip method and hand-sprayer method. In all bioassays 10 to 25 insects were used except for the hand-sprayer method where 50 insects were used per assay. A minimum of five replicates were conducted for each concentration i.e. $0.01 \%$, $0.05 \%, 0.025 \%, 0.0125 \%, 0.006 \%$ and $0.003 \%$. Controls were treated with the solvent only. In all bioassays, the mortalities were recorded $24 \mathrm{~h}$ after treatment.

Potters' sprayer method: A Potters' sprayer (Burcard, Ridemansworth, Herts, England) was used with a spraying air pressure of $0.703 \mathrm{~kg} / \mathrm{cm}^{2}$ and $2 \mathrm{ml}$ Volume of test solution sprayed at a time ${ }^{4}$.

Microapplicator method: A drop $(0.25 \mu \mathrm{L})$ of test solution was applied topically on to the dorsal surface of the thorax of each insect using a hand microapplicator (Burkard, England) ${ }^{16,17 .}$

Leaf dip method: Fresh cabbage leaves were cut into discs (4 cm diameter) and were dipped into the test solution of latex for $5 \mathrm{~s}$. The discs were removed from the test solution and hung vertically for 5 min to allow excess solution to drip off. The discs were next placed in a horizontal position and allowed to dry for a period of $2 \mathrm{~h}$ at room temperature $\left(27^{\circ} \mathrm{C}\right)$. Each treated leaf disc was placed in a petri- dish ( $4 \mathrm{~cm}$ diameter). Insects were then introduced on to the leaf disc ${ }^{4}$.

Hand sprayer method: A 500 mL-hand sprayer (WARDS, USA) was used. The tank of the sprayer was filled with $250 \mathrm{~mL}$ of test solution. One-month-old radish seedlings in plastic pots of $25 \mathrm{~cm}$ (diameter) x $20 \mathrm{~cm}$ (height) (one seedling/pot) were used. Fifty $M$. persicae were introduced on to three selected leaves of each radish seedling. Insects were allowed to settle for half an hour. Four quick sprays, with approximately $5 \mathrm{~mL}$ of the test solution, were applied for each treatment.

\section{Analysis of bioassay data}

Abbott's formula: Bioassay data were not considered if the control mortalities were $>20 \%$. Actual mortalities were calculated against control mortalities $(>20 \%)$ by using Abbott's formula ${ }^{15}$ :

\section{Corrected mortality $=\%$ survival in control experiment - $\%$ survival in treated experiment $\quad$ X 100 $\%$ survival in control experiment}

Log - probit regression lines: Log - probit regression lines were obtained by plotting percentage mortalities ( $\mathrm{Y}$ axis - probability) against concentration ( $\mathrm{X}$ axis - log) using the computer program EPA probit analysis version 
1.5. $\mathrm{LC}_{50}$ (dosage which kills $50 \%$ of the population) and $\mathrm{LC}_{90}$ (dosage which kills $90 \%$ of the population) values were obtained. Fitness of the regression lines was statistically tested using $\chi^{2}$ values.

Duncan multiple range test(DMRT): Percentage mortality values were converted to arc-sine values using an angular transformation table before statistical analysis. The mean values were then subjected to an analysis of variance at $\mathrm{p}=0.05$, followed by DMRT using a Statistical Analysis System (SAS, 2002).

Field experiment: Field trials to determine the bio-efficacy of xylene-latex extracts were conducted in a home garden at Kegalle $\left(7.25^{\circ} \mathrm{N} \& 80.35^{\circ} \mathrm{E}\right)$, Wet Zone of Sri Lanka (Mean monthly rainfall $2250 \mathrm{~mm}$ and mean monthly temperature $27^{\circ} \mathrm{C}$ ). One and half month old radish plants and the aphid pest $M$. persicae were used. Soap, teepol (Sodium dodecylbenzene sulphonate) and newkalgen (polyethylene glycol ether) were used to prepare $0.25 \%$ latex emulsions. One and half month old radish seedlings were planted in 12 plots $(2 \mathrm{~m} \mathrm{x} 1 \mathrm{~m})$, each plot comprising 30 plants. Three hundred adult $M$. persicae were introduced onto the top leaves of each radish plant. Two weeks later, treatments were applied using a hand sprayer. Approximately $400 \mathrm{~mL}$ of latex emulsion was sprayed per experimental plot and $400 \mathrm{~mL}$ of detergent (without the latex) was sprayed per control plot. After $48 \mathrm{~h}$, the number of live aphids on each plant was counted. Treatments were repeated at $5 \mathrm{~d}$ intervals and in each case the number of live aphids on each plant was recorded $48 \mathrm{~h}$ after treatment.

\section{Chemical studies}

Thin Layer Chromatography (TLC): Thin layer chromatography was carried out on Merk 5554 Kieselgel 60F254 pre-coated UV sensitive aluminum foil plates. Preparative Thin Layer Chromatography (PTLC) was done using Merk 7748 silica gel PF254 and Merk 7730 silica gel GF254 coated on microscopic glass plates. Ethyl acetate: petroleum ether $(0.5 \mathrm{~mL}: 9.5 \mathrm{~mL})$ solvent system was used and the plates were developed with anisaldehyde in concentrated sulfuric acid. Ultra violet (UV) sensitive TLC plates were then visualized under UV (254-365nm) light.

Florisil Column Chromatography(FCC): A 25 mL burette with a teflon stopcock was used as the chromatographic column. Florisil (Silica Company USA) PR grade with 60-80 mesh size was activated by subjecting to a temperature of $138{ }^{\circ} \mathrm{C}$ for one week prior to use. Xylene- latex extract $(6 \mathrm{~mL})$ was eluted with $80 \mathrm{~mL}$ of $\mathrm{n}$-hexane at a flow rate of $4 \mathrm{~mL} / \mathrm{min}$ followed by $80 \mathrm{~mL}$ of petroleum ether and $80 \mathrm{~mL}$ of dichloromethane. Elute was collected in $4 \mathrm{~mL}$ fractions. Sixty fractions (each $4 \mathrm{~mL}$ ) were collected and each was tested with TLC using ethyl acetate: petroleum ether (0.5: 9.5) eluent. Each fraction was then screened for insecticidal activity against $M$. persicae using the microapplicator method. The $4^{\text {th }}$ n-hexane fraction, which had the highest insecticidal activity, was further separated by High Performance Liquid Chromatography (HPLC) and Gas Chromatography (GC).

High performance liquid chromatography (HPLC): Hewlett-Packard Agilent 1100 series (Agilent Technologies, USA) with UV 280 detector and agilent Hypersil BDS-C ${ }^{18}$ column [4 m (length) x $100 \mathrm{~mm}$ (diameter)] was used. Typical surface area of the $\mathrm{C}^{18}$ column was $130 \mathrm{~m}^{2}$. A Perkin Elmer 785A UV-visible detector was used. HPLC grade methanol: water mixture (80: 20) was used as the mobile phase with a flow rate of $1 \mathrm{~mL} \mathrm{~min}{ }^{-1}$. One micro litre amount of the test sample was injected manually using a micro syringe and each sample was allowed to run for $45 \mathrm{~min}$.

\section{RESULTS}

\section{Insecticidal activity of the latex}

Control bioassay experiments with the seven solvents i.e. dichloromethane, n-hexane, distilled water, acetone, xylene, methanol and petroleum ether gave less than 5\% mortality. Bioassays with $10 \%$ latex solvent extracts gave $100 \%$ mortalities except for the extract with distilled water $(0 \%)$. Spraying resulted in leaf-scorching with xylene-latex extract and a white mesh formation was observed with n-hexane, dichloromethane and petroleum ether latex extracts. Since the mortalities observed may be due to leaf-scorching / white mesh formation rather than direct insecticidal effect of the tested compounds, the latex extracts were diluted to $0.1 \%$ with relevant solvents and the bioassays were repeated. White mesh formation was still evident with dichloromethane, n-hexane and petroleum ether extracts. Since the xylene-latex extract and the methanol-latex extract gave the highest mortalities (not significantly different from each other) without changing the appearance of the leaves, these two were selected for further studies. Different concentrations of methanol- latex and xylenelatex extracts were sprayed onto $M$. persicae using the Potters'sprayer. Bioassay mortalities were plotted against the concentrations to get log dosage-probit mortality curves (Figure 1). Xylene- latex extract had a lower $\mathrm{LC}_{50}$ $\left(\mathrm{LC}_{50}=0.01 \%\right)$ than that of the methanol- latex extract $\left(\mathrm{LC}_{50}=0.08 \%\right)$ showing that the xylene-latex extract 
is more effective. $\chi 2$ values $(\mathrm{p}<0.05)$ indicated that $M$. persicae showed a homogenous response to dosage changes of both extracts.

The efficacy of the Potters' sprayer method, leaf dip method, hand-sprayer method and mocroapplicator method was deterrmined using $M$. persicae. The microapplicator method could not be used with the crude homogenate as the extract was sticky . $\mathrm{LC}_{50}$ and $\mathrm{LC}_{90}$ values are presented in Table 1 (mortality lines are not shown). Potters' sprayer bioassay method gave the lowest $\mathrm{LC}_{50}$ and $\mathrm{LC}_{90}$ values, within a narrow range of concentration, showing that it is the better bioassay method when compared with the other three. Therefore, this method was used for bioassays with other insect pests and predatory species. In general, it can be stated that all three aphid species, A. craccivora, A. gossypii and $M$. persicae, showed a high level of mortality with xylene- latex extracts (Table 2 and Figure 2). Rice pests L. oratorius, $N$. lugens, and $S$. lurida showed higher $\mathrm{LC}_{50}$

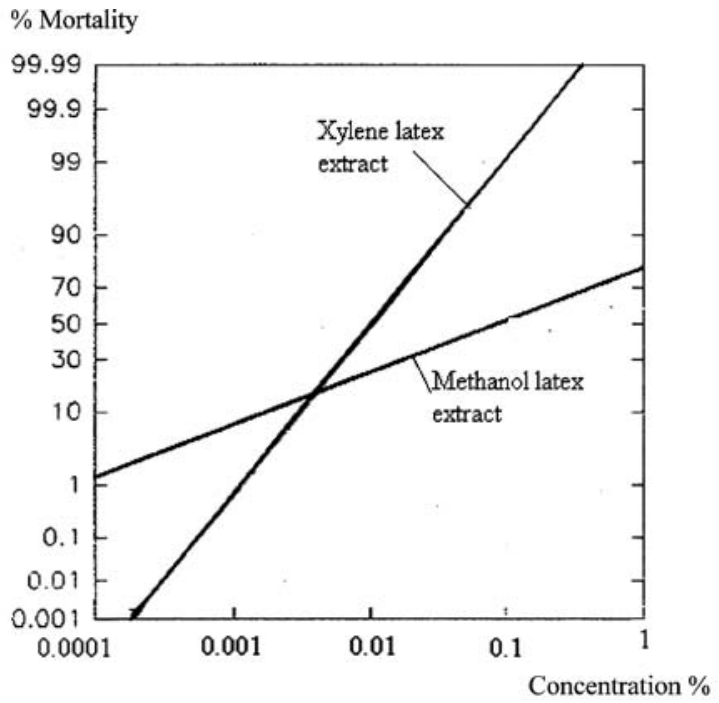

Figure 1: Log dosage-probit mortality lines for xylene and methanol- latex extracts for M. persicae by Potters' sprayer bioassays ( $\mathrm{N}=600$ each extract) values indicating that the active compound/s present in the latex was less toxic to these rice pests than to the aphids A.gossipii, A. caccivora, and M. persicae. Present results also showed that $L$. oratorius is more susceptible than $N$. lugens. Rice insect pest $S$. lurida showed no mortality even at $0.1 \%$ concentration level. Effect of the xylene latex extract was tested against the predatory ladybird beetles $H$. octomaculata and $M$. sexmaculatus and a predatory spider L. pseudoannulata. Both $H$. octomaculata and $M$. sexmaculatus gave $0 \%$ mortality with the highest concentration tested $(0.1 \%)$. In contrast the predatory spider L. pseudoannulata gave $100 \%$ mortality for the lowest concentration tested (0.003\%).

Experiments were also conducted on the insecticidal activity of the latex extract under field conditions (Mean monthly temperature $27{ }^{0} \mathrm{C}$, Mean monthly rainfall $2250 \mathrm{~mm}$ ). Results obtained with different emulsifying agents were not significantly different $(p>0.005)$ when

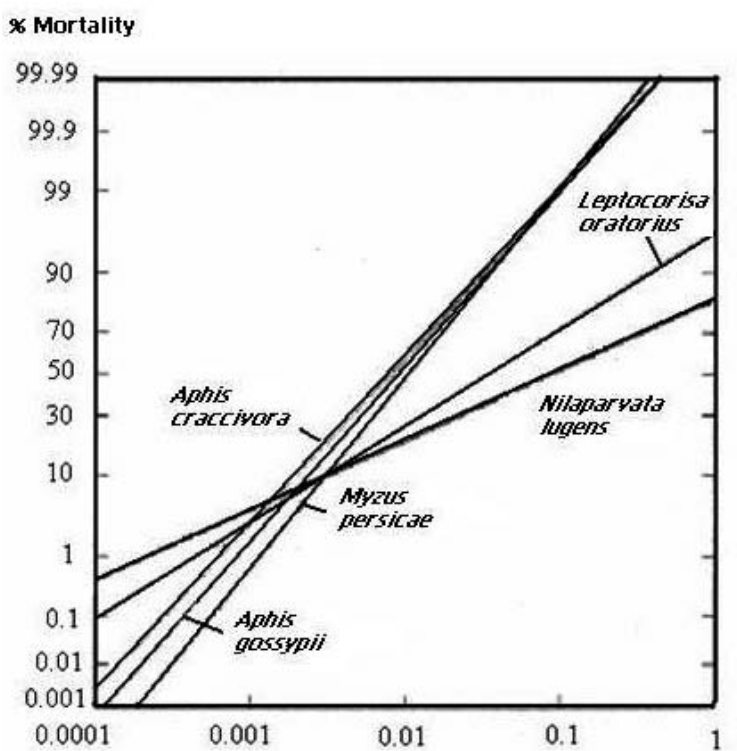

Figure 2: Log dosage - probit mortality lines xylene-latex extract for different insect species by Potters’ sprayer bioassay $(\mathrm{N}=500)$

Table 1: ${ }^{*} \mathrm{LC}_{50}$ and $* * \mathrm{LC}_{90}$ values of $M$. persicae for xylene-latex extracts by using different bioassay methods

\begin{tabular}{|c|c|c|c|c|c|c|}
\hline \multirow[t]{2}{*}{ Insects } & \multicolumn{2}{|c|}{ Potters'sprayer method } & \multicolumn{2}{|c|}{ Leaf dip method } & \multicolumn{2}{|c|}{ Hand sprayer method } \\
\hline & ${ }^{*} \mathrm{LC}_{50} \%$ & $* * \mathrm{LC}_{90} \%$ & ${ }^{*} \mathrm{LC}_{50} \%$ & $* * \mathrm{LC}_{90} \%$ & $* \mathrm{LC}_{50} \%$ & $* * \mathrm{LC}_{90} \%$ \\
\hline \multirow[t]{2}{*}{ M. persicae } & 0.0119 & 0.050 & 0.0961 & 0.906 & 0.1062 & 1.374 \\
\hline & \multicolumn{2}{|c|}{$\begin{array}{l}\mathrm{N}=750, \mathrm{n}=5, \\
\chi^{2}=6.922, \\
(\mathrm{p}<0.05)\end{array}$} & \multicolumn{2}{|c|}{$\begin{array}{l}\mathrm{N}=600, \mathrm{n}=3, \\
\chi^{2}=2.103, \\
(\mathrm{p}<0.05)\end{array}$} & \multicolumn{2}{|c|}{$\begin{array}{l}\mathrm{N}=600, \mathrm{n}=3 \\
\chi^{2}=9.078 \\
(\mathrm{p}<0.05)\end{array}$} \\
\hline
\end{tabular}

$\mathrm{N}=$ total number tested, $\mathrm{n}=$ degree of freedom, ${ }^{*} \mathrm{LC}_{50}$ - Lethal concentration, which kills $50 \%$ of the population,

$* * \mathrm{LC}_{90}$ - Lethal concentration, which kills $90 \%$ of the population. 
Table 2: ${ }^{*} \mathrm{LC}_{50}$ and $* * \mathrm{LC}_{90}$ values of xylene-latex extracts for different insect species tested by Potters' sprayer bioassay.

\begin{tabular}{|c|c|c|}
\hline Insect pests & $* \mathrm{LD}_{50}$ & $* * \mathrm{LD}_{90}$ \\
\hline \multirow[t]{2}{*}{ M. persicae } & 0.0119 & 0.050 \\
\hline & \multicolumn{2}{|r|}{$\mathrm{N}=750, \mathrm{n}=5, \chi^{2}=6.922(\mathrm{p}<0.05)$} \\
\hline \multirow[t]{2}{*}{ A. gossypii } & 0.0077 & 0.034 \\
\hline & \multicolumn{2}{|r|}{$\mathrm{N}=750, \mathrm{n}=5 \chi^{2}=8.612,(\mathrm{p}<0.05)$} \\
\hline \multirow[t]{2}{*}{ A. craccivora } & 0.0089 & 0.047 \\
\hline & \multicolumn{2}{|r|}{$\mathrm{N}=750, \mathrm{n}=5 \quad \chi^{2}=7.627,(\mathrm{p}<0.05)$} \\
\hline \multirow[t]{2}{*}{ L. oratorius } & 0.0335 & 0.404 \\
\hline & \multicolumn{2}{|r|}{$\mathrm{N}=480, \mathrm{n}=4 \chi^{2}=4.479,(\mathrm{p}<0.05)$} \\
\hline \multirow[t]{2}{*}{ N. lugens } & 0.0845 & 3.844 \\
\hline & \multicolumn{2}{|r|}{$\mathrm{N}=480, \mathrm{n}=4 \chi^{2}=12.33,(\mathrm{p}<0.05)$} \\
\hline S. lurida & \multicolumn{2}{|c|}{ above the range tested } \\
\hline L. pseudoannulata & \multicolumn{2}{|c|}{ below the range tested } \\
\hline
\end{tabular}

tested with DMRT. Xylene latex extract with soap gave the highest mortality (18.47\%) followed by teepol (23.79\%) and newkalagen (31.52\%).

Figure 3 gives the percentage mortalities for xylenelatex extracts, collected from the three climatic zones. Dry Zone samples had the highest insecticidal activity whereas Wet Zone samples had the lowest. Results confirmed $(p<0.001)$ that there is a significant difference among the insecticidal activities of xylene- latex extract of the three climatic zones. There were no seasonal variations of the insecticidal activity of the xylene- latex extract (at $0.025 \%$ concentration) collected from the three climatic zones.

\section{Chemical analysis}

Initial chemical analysis of the seven solvent latex extracts of E. antiquorum were performed with TLC. Five clear spots were obtained from the xylene- latex extract whereas three spots were obtained from the methanol- latex extract. Dichloromethane, n-hexane and petroleum ether extracts gave dark streaks which did not exhibit any clear separation. Acetone latex extract gave spots which were not clearly separated. Distilled water latex extract did not result in any spots on the TLC plate. Further experiments showed that the three spots of the methanol- latex extract overlapped with the 3 spots of the xylene- latex extract. The latter showed two additional spots $\mathrm{R}_{\mathrm{f} 1}(0.98)$ and $\mathrm{R}_{\mathrm{f} 2}(0.49)$ (Figure 4 ).
The xylene- latex extract, which showed the highest insecticidal activity and the best TLC profile, was subjected to FCC to separate the active components. Sixty fractions were collected. Each fraction was subjected to TLC. Only the $3^{\text {rd }}$ petroleum ether fraction (one spot) and the $3^{\text {rd }}$ (two spots) and $4^{\text {th }}$ (one spot) n-hexane fractions gave clear spots (Figure 5).

\section{Bioassays using microapplicator for FCC fractions}

Bioassays were conducted with all the FCC fractions i.e. petroleum ether fractions (20), n-hexane fractions (20) and dichloromethane fractions (20), for insecticidal activity against $M$. persicae using a microapplicator. The highest mortality $(53.25 \%, n=100)$ was shown by the $4^{\text {th }}$ n-hexane fraction. Some fractions i.e. third n-hexane, fourth $\mathrm{n}$-hexane and fifth n-hexane fractions showed mortalities around $20 \%$ whereas the other fractions showed less than $20 \%$ mortalities. Since $4^{\text {th }}$ n-hexane fraction showed the highest insecticidal activity and TLC profile with clear spots, this fraction was selected for further studies. Comparative TLC of xylene- latex extract and $4^{\text {th }}$ n-hexane fraction showed that the spot given by $4^{\text {th }} n$-hexane fraction overlapped with $\mathrm{R}_{1}$ spot of xylene-latex extract (both had $\mathrm{R}_{\mathrm{f}}=0.98$ ) (Figure not shown).

$4^{\text {th }}$ n-hexane fraction gave three peaks with HPLC (Figure 6). Third n-hexane fraction, which had an insignificant level of insecticidal activity, was used as a 


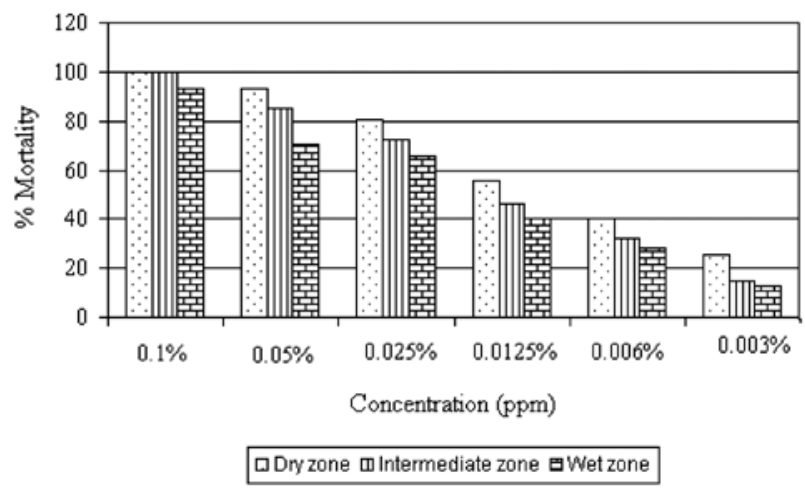

Figure 3: Insecticidal activity of xylene -latex extracts prepared from the latex collected from different climatic zones (bioassays were done by Potters' sprayer method with M. persicae $)(\mathrm{N}=600$ per zone $)$

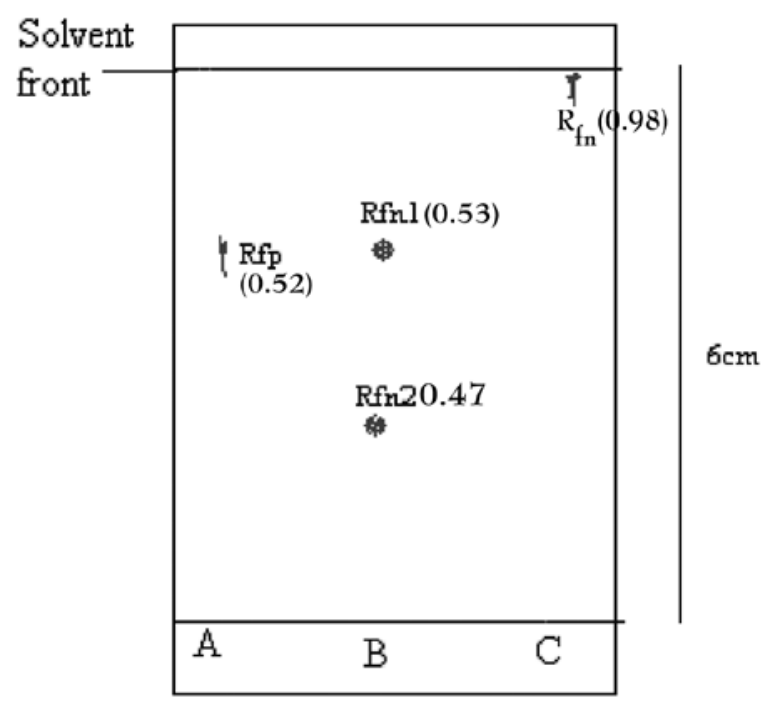

A- 3rd petr.ether fraction of xylene- latex extract B- 3rd n-hexane fraction of xylene- latex extract

C- 4th n-hexane fraction of xylene- latex extract

Figure 5: Thin layer chromatogram, spots shown by column chromatographic fractions (florisil) of xylene-latex extract with ethyl acetate: petroleum ether (1:19) solvent system

control. Latter gave only two peaks with retention time of 0.782 and 1.256. Superimposed chromatogram of $3^{\text {rd }}$ and $4^{\text {th }}$ n-hexane fractions showed that 0.782 and 1.256 peaks are present in both fractions but an additional 1.006 peak was present in the $4^{\text {th }}$ n-hexane fraction (Figures not shown). To determine whether the peak with retention time of 1.006 is present in the original extract, xylene-latex extract was also subjected to HPLC. The xylene-latex extract gave six peaks (Figure 7) including a peak with retention time 1.003. Chromatograms of xylene-latex extract and $4^{\text {th }}$ n-hexane fraction were

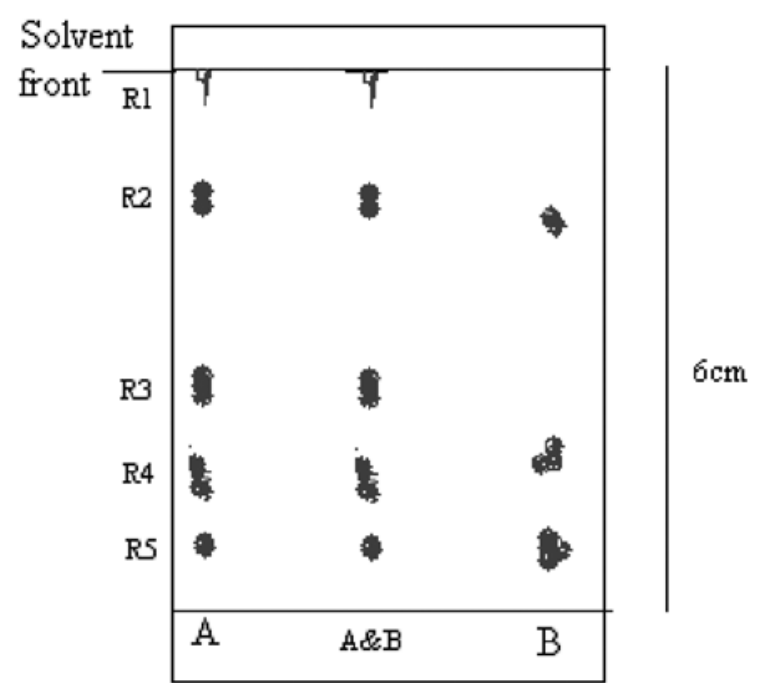

$\mathrm{R} 1=0.98, \mathrm{R} 2=0.59, \mathrm{R} 3=0.49, \mathrm{R} 4=0.35, \mathrm{R} 5=0.15$

A- Xylene- latex extract

B- Methanol -latex extract

Figure 4: Comparative thin layer chromatogram of methanol-latex extract and xylene-latex extract with ethyl acetate:petroleum petroleum ether $(1: 19)$ solvent system

superimposed and the results confirmed that both peaks were the same (Figure not shown).

Stability of the insecticidal activity of the xylene-latex extract and $4^{\text {th }}$ n-hexane fraction was tested at monthly intervals using Potters' sprayer method and microapplicator method respectively. Both extracts were stored at $4{ }^{\circ} \mathrm{C}$. Only a $3 \%$ reduction of the activity of both xylenelatex extract and $4^{\text {th }}$ n-hexane fraction occurred during a period of one year (refrigerator temperature $4^{\circ} \mathrm{C}$ ).

\section{DISCUSSION}

Various plants belonging to family Euphorbiaceae have been studied worldwide for their cytotoxic constituents. E. elbractolata, Croton laciferus, E. pekinensis, Jatropa curcas and E. lathyris are a few of the Euphorbiaceae plants that have been studied for toxic constituents ${ }^{4,13 \text {, }}$ ${ }^{19,20}$. Carcinogenic properties of latex of Euphorbiaceae plants have been reported by various scientists although there are no records on co-carcinogenic activities of constituents of the latex of E. antiquorum ${ }^{10,21}$. Only a few researchers have conducted studies to elucidate insecticidal activities of Euphorbiaceae plants in Sri Lanka ${ }^{4,5,14}$. 


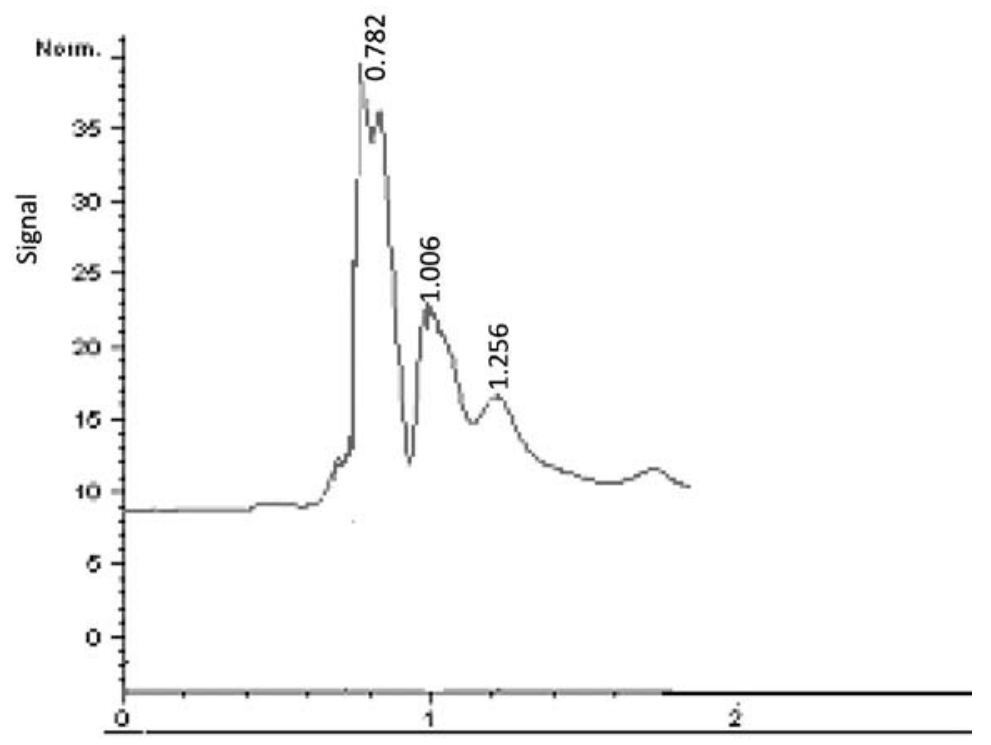

Figure 6: High performance liquid chromatogram of the 4th n-hexane fraction of xylene-latex extract\{Solvent system methanol: water mixture (80:20); Perkin Elmer 785A UV-visible detector\}

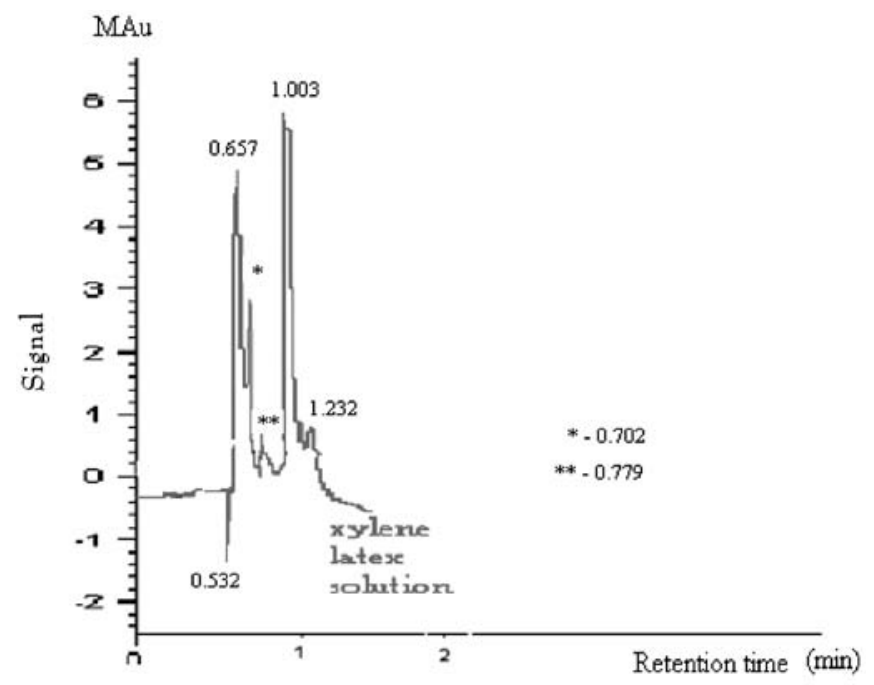

Figure 7: High performance liquid chromatogram of xylene -latex extract \{Solvent system methanol: water mixture (80:20);Perkin Elmer 785A UV-visible detector\}

During the present study, the latex of E. antiquorum was tested against common and widely spread pest species of vegetables and rice and also against some of their natural enemies. These insects pests are considered to be more resistant to synthetic insecticides ${ }^{22,23}$. Results revealed that the latex of $E$. antiquorum L. is an effective insecticidal agent because both crude extract as well as partially purified extract caused more than $50 \%$ mortality of tested aphid populations. The observed $\mathrm{LC}_{50}$ of M. persicae with E.antiquorum latex extract (0.012\%) was, however, greater than that with Azadirachta seed oil
$(0.0024 \%)^{24}$. However, E. antiquorum latex extract was not effective against insects with thick cuticle covers. Although soft-bodied natural enemies like spiders are susceptible to the latex of E. antiquorum, most common and important natural enemies like ladybird beetles are highly resistant. According to the results it can be concluded that active compounds of the latex can be success fully extracted with less polar solvents like xylene.

The results revealed that the Potters' sprayer method is an appropriate method for insect bioassays with the 
latex extracts. Field experiments also indicated the success of latex as a pesticide against certain insect pests under actual farming conditions. The study revealed that florisil could be successfully used to partially purify the active compounds of the latex. This can be done on a large scale and the partially purified product can be made available in the market. Results of the study showed that a cheap and common detergent like soap could be used to prepare the final formulation using either the crude latex extract or the partially purified product. The study demonstrated that both the crude extract and the partially purified products of the latex are very stable under storage conditions $\left(4^{\circ} \mathrm{C}\right)$ and retain their insecticidal properties up to one year.

E. antiquorum is a widely distributed plant found all over the world and can be easily cultivated to obtain the raw material required for the large-scale production of the latex/partially purified product. According to the results of this study, the latex of E. antiquorum from the Dry Zone is more effective than latex from the Wet Zone and the Intermediate Zones. The insecticidal activity of latex samples collected monthly does not show significant variations.

Further investigations are necessary to isolate the active insecticidal compounds of the latex and study the insecticidal effects of these compounds.

\section{Acknowledgement}

We thank the National Science Foundation of Sri Lanka for financial assistance through the grant NSF/RG/99/ $\mathrm{C} / 12$.

\section{References}

1 Raveendranath S. (1999). Eco-friendly pesticides. Sri Lanka Association for the Advancement of Science, Seminar on pest control in the next millenium, University of Ruhuna, Matara. pp. 47-53.

2. Hewage C.M., Bandara K.A.N.P., Karunaratne V., Bandara B.M.R. \& Wijesundara D.S.A. (1997). Insecticidal activity of some medicial plants of Sri Lanka. Journal of the National Science Council of Sri Lanka 25(3): 141-150.

3. Rafael E. (2001). Botanical insecticides. www.ipmworld. umn.edu/silvia.html. Accessed on 12 October 2001.

4. Bandara B.M.R., Wimalasiri W.R. \& Macleo D.J.K. (1988). Ent -Kauranes and oleananes from Croton laciferus. Journal of phytochemistry 27(3): 869 -871.

5. Bandara R.M.B., Wimalasiri W.R. \& Bandara K.A.N. (1987). Isolation and insecticidal activity of (-) hard wickiic acid from Croton aromaticus. Tetrahedron Letters 22(24):575-577.
6. Tona L., Kambu K., Mesia K., Cimanga K., Apers S., De Bruyne T., Pieters L.,Totte J. \& Vlietinck A.J. (1999). Biological screening of traditional preparations from some medicinal plants used as anti-diarrhoeal in Kinshasa, Congo. Journal of Phytochemistry 6 (1): 59-66.

7. Mucsi I., Molnar J., Hohmann J. \& Redei D. (2001). Cytotoxicities and anti-herpes simplex virus activities of diterpenes isolated from Euphorbia. Journal of Planta Medica 67(7): 672-674.

8. Liu W.K., Ho J.C., Qin G., Che C.T. (2002). Jolkinolide B induces neuroendocrine differentiation of human prostate LNCaP cancer cell line. Biochemical Pharmacology 63(5): 951-957.

9. Evanics F., Hohmann J., Redei D., Vasas A., Gunther G. \& Dombi G. (2001). New diterpene polyesters isolated from Hungarian Euphorbia species. Acta Pharmaceutica Hungerica 71 (3): 289-292 .

10. Evans F.J. \& Kinghorn A.D. (1973). Proceedings: A screening procedure for Euphorbia co-carcinogenic irritants. Journal of Pharmacy and Pharmacology 25:145146.

11. Farnsworth N.R., Wagner H., Horhammer L., Horhammer H.P. \& Fong H.H.(1968). Euphorbia esula (Euphorbiaceae), preliminary phytochemical and biological evaluation, Journal of Pharmaceutical Sciences 57(6): 933-939.

12. Anjaneyulu V. \& Ravi K. (1989). Terpenoids from Euphorbia antiquorum. Journal of phytochemistry 28 (1): $1695-1697$.

13. Adebowale K.O. \& Adedire C.O. (2006). Chemical composition and insecticidal properties of the underutilized Jatropha curcas seed oil. African Journal of Biotechnology 5 (10): 901-909.

14. Palugaswewa J. (1998). Insecticidal activity of Euphorbia antiquorum latex. M.Sc. Thesis, Postgraduate Institute of Science, University of Peradeniya, Peradeniya.

15. Matsumura F. (1985) Toxicology of insects. second edition. Plenum Press, New York, USA.

16. Beranek A.P. (1974 a). Esterase variation and organophosphate resistance in populations of Aphis fabae and Myzus persicae. Entomologia Experimentalis et Applicata 17: 129-142.

17. Beranek A.P. (1974b). Stable and non-stable resistance to dimethoate in the peach potato aphid (Myzus persicae). Entomologia Experimentalis et Applicata 17: 381-389.

18. Bandara K.A.N.P., Perris I.D.R., Kumar V., Karunaratna V., \& Ranasinghe M.A.S.K. (1990). Insecticidal activity of Acorus calamus and Glycosmis mauritiana (Lam) Tanaka against Aphis cracivora. Tropical Agriculture 6 (3): 223228.

19. Akihisa T., Wijeratne K., Tokuda H., Enjo F., Toriumi M., Kimura Y., Koike K., Nikaido T., Tezuka Y. \& Nishino H. (2002). Eupha-7, 9 (11), 24-trien-3ß-ol ("antiquol C") and other triterpenes from Euphorbia latex and their inhibitory effects on Epstein-Barr virus activation. Journal of Natural Products 65(2): 158-162.

20. Bicchi C., Appendino G., Cordero C., Rubiolo P., Ortelli D. \& Veuthey J.L. (2001). HPLC-UV and HPLC-positive-ESI- 
MS analysis of the diterpenoid fraction from caper spurge (Euphorbia lathyris) seed oil. Journal of Phytochemistry 12 (4): 255-262.

21. Salah M.A.D., Zayed M.F., Hubert G. \& Erich H. (1998). Dietary cancer risk conditional cancerogens in produce of livestock fed on species of spurge (Euphorbiaceae). Journal of Cancer Research and Clinical Oncology 124 (4):131-140.

22. Bambarandage T.D. (2001). Status of insecticide resistance and resistance mechanisms in some of the insect pests of vegetables and two insect predators.
M.Phil. Thesis, pp. 40-51, 70-90. Postgraduate Institute of Science, University of Peradeniya, Peradeniya.

23. Weerakoon K.C. (2003). Status of insecticide resistance and resistance mechanisms in some of the rice insect pests and four of their predators. M.Phil. Thesis, pp. 88-94.Postgraduate Institute of Science, University of Peradeniya, Peradeniya.

24. Lowery T.D. \& Murray B.I. (1994). Insect growth regulating effects of neem extract and azadirachtin on aphids. Entomologia Experimentalis et Applicata 72(1): 77-84. 